\title{
Local culture-based picture storybooks for teaching English for young learners
}

\author{
Ni Made Ratminingsih ${ }^{1 *}$ and I Gede Budasi ${ }^{1}$ \\ ${ }^{1}$ English Education Department, Universitas Pendidikan Ganesha, 81116 Singaraja-Bali, Indonesia
}

\begin{abstract}
This paper reports the theoretical perspectives underlying the development of local culture-based picture storybooks for teaching English for young learners. It is a library research which derives from three main sources, journal articles, reference books, and internet articles. Local culture-based picture storybooks are kinds of printed materials which basically contain stories adapted from local culture stories accompanied with visualization in the forms of pictures telling the characters and the settings to help young learners easily understand the stories. They are developed considering the good criteria of storybooks [1,2]. The benefits of its development are (1) to improve reading skill of young learners, (2) to build children English literacy through listening to the story read by the teachers and communicating interactively with them through dialogic reading, (3) create a fun learning atmosphere which enhances motivation and participation to take part in understanding and using the language, and (4) to preserve local culture. The books are developed using a combination of model $[3,4]$ which has 5 main steps namely need analysis, developing product, expert validation, and quality assessment by experts and users (teachers), and main product revision.
\end{abstract}

Keywords: local culture, storybooks, young learners

\section{Introduction}

Teaching English for young learners (TEYL) should be given as early as possible because early introduction can enhance acquisition. English competence is beneficial to prepare professional working forces that are able to be competitive to get job vacancies in tourism sector and other fields as well as for science and technology advancement in ASEAN Economic Community. The importance of introducing English early is for better and quicker target language acquisition [5]. However, the reality shows that Indonesian learners possess low interest in reading. A research reports [6] that most of the students in Indonesia do not have good reading habit though they spend approximately 10 to 11 years to learn English formally from primary to tertiary level.

In fact, reading is one of the language skills which are important. Through reading, learners can improve their knowledge. Reading stories, story-based approach, is

* Corresponding author: made.ratminingsih@undiksha.ac.id 
emphasized to positively affect toward environment which stimulates a higher level of intrinsic motivation and engagement of young learners in primary school [7].

Empirically, a research found that the use of story could motivate young leaners besides build enjoyment and happiness [8]. Moreover, a study also proved that teaching young learners by using story had a strong effect on students' listening and speaking performance [9]. Another study also revealed that teaching by using pictures could support independent reading, develop reading strategies, as well as foster reading motivation [10]. Henceforth, in order to improve students' interest in reading, it is necessary to develop picture storybooks as the main focus of this study. By using this kind of books, the learners can be more interested in reading and more motivated to understand the massage of the stories. Furthermore, through local culture-based stories, English instruction can be made contextual, in which the contents of the stories used local culture which becomes parts of the learners' life, since the familiarity of the topics could decrease cognitive pressure they face [11]. Thus, they can use the language for communicative purposes. In addition, they can also be directly involved in creating interactive dialogue in the process of story reading through dialogic reading. By conversing, they are able to practice communicating while trying to understand the stories. More importantly, through the insertion of local culture young learners will respect, love, and preserve values of local culture. This is the main focus of this current research since the tradition of reading folklores has been decreasing among Indonesian young generation because of technology influence. They tend to enjoy more of the technological games rather than books. Therefore, the purpose of this research is to develop local culture-based picture storybooks for young learners. There are three research questions which become the focus of this study: (1) what is meant by local culturebased picture storybooks and what criteria are used to develop these books?, (2) why is it beneficial to use local culture-based picture storybooks?, and (3) how is the procedure to develop these local culture-based picture storybooks?

\section{Method}

This paper is the result of library research which obtains the data from three sources, namely journal articles, reference book, and articles of research journals.

\section{Results and discussion}

\subsection{The nature of TEYL and local culture-based picture storybooks}

Young learners do not understand yet abstract concepts which is different from adult learners $[12,13]$. They focus on concrete concepts of learning. Based on this fact, the teacher should more emphasize on the concretization in learning a foreign language without giving them the abstract concept, in order to ease young learners in understanding the lesson. Young learners are students who are at pre-primary and primary level, from the age of 3 up to 11 or 12 years old [14]. Specifically, there are some important characteristics of young learners $[15,16]$, namely: (1) young learners have a short attention, (2) they are active learners, (3) they are happy with appreciation, (4) they do not feel embarrassed, (5) they like to imagine, (6) they love to play [17], and (7) they like to imitate what they hear.

Based on the above characteristics, it can be inferred that young learners get bored quickly, be less motivated to learn with difficult tasks, like to imagine, be active, playful, and never shy. Thus, their reading interest can be increased through the use of colorful picture storybooks. They can imagine the characters and places in the storybooks and the vocabulary can be easily understood through pictures. Young learners are also directed to 
be active in the sense of the story read by teacher, then they actively imitate the vocabulary and sentence, and involve in conversing interactively in the process of understanding the story, so that the power of reasoning can be developed. Therefore, their reading competence will be improved, especially in the form of reading comprehension.

There are two kinds of reading, intensive and extensive reading. Intensive reading requires a deep understanding, while extensive reading is more to do with gaining general understanding to develop good reading habits and to encourage reading for pleasure [18]. It is further stated that reading for pleasure refers to reading which is started at other's request then we continue since we are getting interested in. Reading for pleasure is defined as a reading in which students choose to do reading based on their own [19]. As been noted that reading has benefits such as learners' literacy competence is developed since they read for pleasure and learners who read and enjoy reading make them to be a literate [20]. It provides a means of everyday life information seeking for young teenagers [21]. It helps learners to improve their skills and learn about themselves, their relationships, values, and all that helps them to make transition to adulthood. Thus, reading for pleasure is a type of reading in which readers like to read based on their willingness for self-satisfaction and get the benefits out of what they read.

Picture storybook is a kind of books that integrates the use of text with image created to present aesthetic value. This type of storybook is a unique genre of text in children's and teenage literature, categorized in terms of format rather than content. The use of images is helpful to bridge the meaning and content, to prompt for discussion, to seek access and complement of written language [22]. There are 4 types of storybooks, namely folktale, fable, legend, and myth which are developed by considering local culture.

Concerning with the local culture, it is a culture that exists in a society in a particular place. Local culture is the most basic culture which is possessed by the local community in terms of ideas, beliefs, rules, and materials [23]. In this study, local culture refers to culture of Balinese society in which it is classified into fourteen elements that are influenced by Hindu or Javanese Hindu beliefs [24]. Some of them are related to this research such as the creation of religious literature (Tutur, Ketattwan, Kanda, Aji, etc.) and the habit of using palm leaf in writing stories, fairy tales, dramas, and others. In relation to the effort of inserting local culture into English learning, the integration of local culture into English learning does not only educate learners about indigenous cultures within their own countries and in the world, but also make English language learning more relevant for learners [25]. Therefore, it can be concluded that the insertion of local culture in learning English is something that is crucial done by educators to provide cultural education and make learning more relevant to the learners where they live and raise.

\subsection{The benefits of using local culture-based picture storybooks}

Local culture-based picture storybooks have a lot of benefits. Students who study local culture are able to improve their reading ability [26]. In addition, story can motivate young learners and create a happy and enjoyable learning environment [8]. In line with that statement, a report also states that teaching stories to EFL young learners are able to give a strong effect on improving listening and speaking performance of them [9]. Additionally, it is believed that picture books can support independent reading, develop reading strategies, and foster reading motivation [10]. Furthermore, the use of stories in English class is appropriated as teaching tools to offer opportunities using English through the repetition of language pattern and vocabularies [27]. Therefore, inserting story of local culture in English learning can improve students' competence specifically reading competence.

Based on preliminary research, there are no local culture-based picture storybooks which are available on sale in the market. The book commonly used by teachers is a student 
workbook or textbook that is not contextual to the local culture. Thus, developing this kind of storybooks has some benefits such as (1) increase students' reading interest by giving materials of reading for pleasure since books packed with images based on topic familiarity in local culture can increase interest and motivation, (2) introduce contextual English vocabulary, which is a local cultural context that can facilitate the comprehension of reading content, (3) lead children to learn to read through dialogue (dialogic reading) in order to construct their own knowledge and use the language in an interactive communicative manner, (4) enhance students' love and appreciation of local culture and as an effort to preserve the culture, and (5) insert character education represented by characters in the story.

Henceforth, it can be concluded that the use of local culture-based picture storybooks for TEYL plays as important teaching tools to enhance students' reading competence through pleasant learning environment with familiar context of learning.

\subsection{The steps of developing local culture-based picture storybooks}

There are 5 steps in developing local culture-based story books used in this study [3, 4]. The explanations of the steps are presented as follows.

\subsubsection{Needs analysis}

Needs analysis is conducted by interviewing 9 teachers of 9 primary schools in 9 districts in Buleleng Regency in order to find out whether or not they use local culturebased picture storybooks in teaching English to young learners. Besides that, observation was also done to see how the teacher commonly teaches English, what strategies and media used, and the tendency of using stories in the teaching English.

\subsubsection{Developing product}

In developing the product, the researcher follows the criteria of a good picture book such as it contains 32-48 pages, the words are approximately 200-1500, it uses simple plot with one until three main characters, and the book is appropriate for children age around 410 years old [2]. Besides that, the researcher also considers the criteria of good story book, namely having a conflict, at least one main character, interesting colored and mood reflecting illustrations, and accuracy and variety of cultural markers in making description (varied skin tones, facial features, body types, hair styles/ textures, clothing, homes, language patterns, and names) [1]. Before developing the prototype of the books, the researcher needs to make a draft in the form of dummy books. It refers to a plan of the product which contains scene, text, and illustration.

\subsubsection{Expert Validation}

The content validity is carried out by two expert judges who give evaluation on the relevancy of the book based on the combination of good criteria of picture book and story book $[1,2]$ which covers 8 dimensions. Taking into account, the content validity was measured by using Gregory Formula. Additionally, the expert judges are also provided with comment slot for giving suggestion for revising the product, if any. 


\subsubsection{Quality assessment by experts and users}

The quality assessment by experts and users (teachers) is administered after finishing the content validity of the local culture-based picture storybooks. It is designed using Likert scale containing range 1 to 5 (poor, below average, average, good, and excellent).

\subsubsection{Main product revision}

This step is conducted after the products, the local culture-based picture storybooks, have been given judgment and comments by experts and users (teachers). Both judgment and comments are used to improve the quality of the contents.

\section{Conclusion}

Local culture-based picture storybooks are teaching media for young learners which cover local culture stories in the form of printed books. These books consist of four types of folklore, namely myth, fable, folktale, and legend. The use of local culture-based picture storybooks is important since it can enhance young learners' reading skill, create enjoyable learning, and build young learners' English literacy, as well as preserve local culture. In developing local culture-based picture storybooks, there are five steps followed, need analysis, developing, expert validation, quality assessment, and main product revision.

The authors of this paper are very grateful to all teachers who had been very helpful and informative to give information needed for this research. Special appreciation is forwarded to the team of the research who spent his valuable time for the research.

\section{References}

1. M. J. Wilcox, K. M. Murphy, C. K. Bacon, S. Thomas, Improving Language Teaching Practice in Preschool Classroom (Arizona State University, Arizona, 2001)

2. M. Rahardjo, H. D. Waluyanto, A. Zacky, JTE, 6, 1 (2006)

3. W. R. Borg, M. Gall, Educational research: An introduction fourth edition (Longman, New York \& London, 1983)

4. K. Hyland, Second language writing (CUP, New York, 2003)

5. J. Harmer, The practice of English language teaching (Essex, Pearson Education Ltd., 2007)

6. E. Iftanti, TEFLIN J, 23, 2 (2012)

7. C. Li, P. Seedhouse, EFL J Quartely, 12, 2 (2010)

8. C. Mart, ELT, 5, 5 (2012)

9. S. Wu, The Internet TESL J, 14, 1 (2008)

10. S. Brunsmeier, A. Kolb, CLELE J, 2 (2017)

11. C. Alwasilah, TEFLIN J, 17, 1 (2006)

12. Juhana, AJEEL, 2, 1 (2014)

13. K. Klein, English Teaching Forum, 43, 1 (2005)

14. F. Copland, S. Garton, ELT Journal, 68, 3 (2014). 
15. N. M. Ratminingsih, JIP, 18, 1 (2012)

16. N. M. Ratminingsih, JIP, 20, 1 (2014)

17. E. Gürsoy, S.C. Korkmaz, ELT Research Journal, 1, 2 (2012)

18. F. Liu, IES, 3, 3 (2010)

19. B. E. Cullinan, Res. J. AASL, 3 (2000)

20. R. K. Kavi, S. N. Tackie, K. A. Bugyei, PROFILE ITPD, 12, 1 (2015)

21. A. Medaille, EBLIP, 7, 3 (2012)

22. L. Moses, Language and Literacy, 17, 3 (2015)

23. J. A. Balshek, ARECLS, 3 (2006)

24. I. M. S. Dharmayuda, Kebudayaan Bali: Pra Hindu, masa Hindu, dan pasca Hindu (CV Kayumas Agung, Denpasar, 1995)

25. S. C. Barfield, J. Uzarski, ETF, 1, 1 (2009)

26. Y. S. Yembise, IJELT, 6, 2 (2010)

27. J. R. A. Tonelli, H.O. Lima, IJHSS, 3, 19 (2013) 